\title{
The Higher Technical Education in the Light of Contemporary Economic Development: Challenges for the Member States of the Eurasian Economic Union
}

\author{
Miras Zhiyenbayev ${ }^{1, a *}$ \\ 1 Karaganda State Technical University, 100027, 56 Mira ave., Karaganda, Kazakhstan \\ azhienbaev.miras@yandex.kz \\ ${ }^{*}$ Corresponding author
}

\begin{abstract}
Keywords: institutional approach, global challenges, economic development, new technological order, re-industrialization, digital economy, institutional limitations of innovative development, higher technical education system, Kazakhstan, Russia, Eurasian Economic Union
\end{abstract}

\begin{abstract}
The article analyzes the state of the contemporary economy of the countries-members of the Eurasian Economic Union, Kazakhstan and Russian in particularly, and higher technical education through the prism of the global challenges the two largest economies of the EAEU are facing at the moment. Special attention is paid to the institutional constraints of the innovative development these two countries have.
\end{abstract}

\section{Introduction}

Facing the global "development challenge", the essence of which was the exhaustion of the possibilities for further growth within the current technological order, all developed and dynamically developing countries of the world have begun to form a new economic paradigm, developing and implementing technological modernization and restructuring the existing economic systems. The countries of the Eurasian Economic Union (EAEU), Kazakhstan and Russia in particular, are late in the beginning of the new technological revolution due to a number of circumstances (both internal and external). However, without a breakthrough to the new technological order, Kazakhstan and Russia can lose their technological advances and technological sovereignty and even experience deindustrialization [9].

Higher vocational education, including technical, serves, on the one hand, as a subsystem of the national economy, and in this capacity it faces the same general problems as the economy as a whole. On the other hand, it is one of the basic resources for the formation of the personnel and innovative potential of the economy. The economy itself, in turn, forms more stringent requirements for the quality of training of specialists in the face of global challenges.

\section{Materials and methods}

Such interconnection and interaction of the two systems predetermined the research methodology. It was based on an institutional approach and system analysis. In particular, the research relies on the regulatory documents of the Government of the Republic of Kazakhstan and the Government of the Russian Federation, materials of the International Economic Forum in St. Petersburg in 2018, data from the official statistical databases, and published literature on the issues of technical education and economic development.

The main objectives of the study include: (i) consideration of the general contour of the emerging technological order in the leading countries of the world; (ii) analysis of the leading trends in the economies of the EAEU member states, particularly Kazakhstan and Russia, through the prism of global challenges they face at the moment; (iii) assessment of the role of higher technical education in the implementation of the innovative breakthrough of the EAEU member states' economies.

The process of formation of a new technological structure has received the name of a new industrial revolution, which in fact has already begun in the developed countries of the world. What are its main directions, determining its essential features? 


\section{The new technological order}

First of all, the basis of the fundamental changes in the modern technological order is the formation of a new model of the economic system - the digital economy. Within this model, the production structure of enterprises and their management undergo a radical transformation. Due to global networks, horizontal interaction between various economic entities is widely developed, which allows faster exchange of resources, increases production, flexibility, and adaptability to rapidly changing consumer needs [12, 13].

Another feature of the emerging technological order is the high proportion of intellectual content in the final product. Hence the crucial role belongs to the first-class specialists in the development and implementation of new technologies in production.

A sign of the new technological order was the mutual influence of nanotechnology, biotechnology, and cognitive science, which is very often called "NBIC" (after the first letters: N-nano, B-bio, I-info, and Ccogno) [12]. The synergistic effect of this interaction is extremely high.

The essence of the global challenges for Kazakhstan and Russia was recognized in a timely manner by the economic and political elites of these countries, which was reflected in a number of strategic government documents (see, for instance, [4]). For Russia and Kazakhstan, it is fundamentally important that their economies continue to be part of the world economy and not be on its sidelines. Meanwhile, the economies of both countries remain significantly behind the leading countries. This lag, the decline in the qualitative parameters of the domestic economy was the result of an erroneous economic strategy pursued by the postSoviet governments since the early 1990s. A structure of a typical post-Soviet economy is still dominated by the extractive industries, and the share of the manufacturing industry among high-tech industries is relatively low. Therefore, the share of the imported equipment acquired by such strategic industries as machine-tool construction, electronic industry, pharmaceutical and medical industries is $80 \%$ in Russia, for instance, and in some industries it reaches $90 \%$ [6].

An even more dangerous trend in the economies of the EAEU countries is the reduction of gross expenditures on research and development (CDPI), including on basic research. Russia is a clear example of such trends. According to the forecasts of the Ministry of Economic Development of Russia and the Ministry of Finance, in 2017 the share of CDPI was just 1\% of the GDP. It will be $0.9 \%$ of the GDP in 2018-2021. And only in 2022 it should again reach 1\%. The state funds investing in research and development in 2017 decreases to $65.1 \%$ (it was $69.2 \%$ in 2014). According to a number of forecasts, it should be $62.7 \%$ in 2018 and up to $59.9 \%$ in 2019-2020 [5]. Such a short-sighted approach by the state makes Russia less competitive in the struggle for technological leadership. This thesis is clearly confirmed by the data in Table 1.

TABLE 1. THE SHARE OF INVESTMENTS AIMED AT RECONSTRUCTION AND MODERNIZATION IN THE TOTAL VOLUME OF INVESTMENTS IN FIXED CAPITAL BY TYPES OF ECONOMIC ACTIVITY IN THE RUSSIAN FEDERATION (\%).

\begin{tabular}{|l|l|l|}
\hline \multicolumn{1}{|c|}{ Investment share } & 2005 & 2016 \\
\hline $\begin{array}{l}\text { Total, } \\
\text { including }\end{array}$ & 21.7 & 16.3 \\
\hline Production of office equipment and computing equipment & 30 & 20.7 \\
\hline Production of electrical machinery and electrical equipment & 31 & 16.5 \\
\hline $\begin{array}{l}\text { Production of electronic components of equipment for radio, television } \\
\text { and communications }\end{array}$ & 32 & 18.3 \\
\hline Production of machinery and equipment (without military equipment) & 38.9 & 17.9 \\
\hline
\end{tabular}

Source: Federal State Statistics Service of the Russian Federation (2018).

According to the World Intellectual Property Organization, in 2015 Russia ranked eighth in the world in the number of national patent applications filed by residents, however, the contribution of enterprises in the business sector was only 13\% [5]. The same situation is observed in Kazakhstan. Actually, bot Kazakhstan and Russia's share in the global market for high-tech products is now less than $1 \%$ (for comparison, the share of the United States is $36 \%$, Japan has 30\%) [7].

Copying the achievements of developed countries in modern conditions is a dead end, since efforts under this approach are aimed at creating what the developed countries are already refusing to do. 
When working on an economic development strategy as a basis for economic policy, it is important not only to track the leading trends in the development of the national and global economy, but also one should understand which factors are the institutional constraints to the innovative development of the national economy, including the industrial sector.

The first such restriction should focus the monopoly of the state in the manufacturing industries, which is a well-known fact for Kazakhstan and Russia. The high volume of government orders and the lack of real competition have formed a certain attitude of industrial enterprises to the need for innovation.

The lack of incentives for industrial enterprises to introduce new industrial technologies is not only a powerful institutional constraint, but also a consequence of the inflexible tax policy of the state, numerous administrative barriers, and a high social insurance burden. All this leads to a reduction in investment by Kazakh and Russian industrialists in innovative technologies [6]. At the same time, the experience of highly developed countries shows that it is private companies that are much more efficient in developing and introducing innovative technologies.

The following limitation is associated with serious structural changes in the field of science and education as a result of the reform. The number of research organizations decreased both in Russia and Kazalhstan. The largest number of research organizations is now concentrated in the field of higher education [8]. But the big question is about the potential of university science and the quality of research work.

In the modern world, higher professional education is becoming one of the most important elements of geopolitics and the economic strategy of states in conquering new markets. It is increasingly becoming a way to promote the country in a globalizing labor market and the international market for new technologies.

\section{Higher technical education}

The system of higher education in Kazakhstan and Russia over the past decade has undergone radical changes. However, educational reforms in these two countries led to very ambiguous results. Instead of a breakthrough in national education towards new achievements, there was a loss of the leading positions that the Soviet high school once occupied. The main reason is the hasty destruction of the national education system, a non-system approach to its reform, and the superficial borrowing of foreign experience. Having copied the western education system, Kazakhstan and Russia did not take into account that in a number of European countries the need to follow the Bologna Convention was of advisory nature and had to complement national educational programs. In Kazakhstan and Russia, it was adopted as a basis for the training of professional personnel. The situation with education in the former Soviet countries still looks very dramatic [1].

Of all the problems of higher technical school, we have identified the main two.

1. The problem existing at the "entrance" is the difficulty with recruiting and competitive selection of future students due to the loss back in the 1990s. The prestige of engineering professions among high school graduates and their low basic level of knowledge in mathematics, physics, chemistry pose a very serious threat. In addition, the hasty transition of colleges to the two-level training system did not allow students to fully master the program for 4 years. But the most important question is the quality of training of future specialists. It still remains open.

A rare technical university (with the exception of the leading ones) today has a modern research base. This negatively affects the level of scientific activity of teachers and the quality of technical education.

Increasingly, employers are expressing dissatisfaction with the weak correlation between university education and real production. This criticism is true, since many professionals left the system of higher education, and inviting leading specialists of specialized industries and scientific research institutes as lecturers (as was the case in Soviet times) is difficult due to the lack of sufficient funds from universities. The consequence of the lack of integration of higher education institutions with the industrial sector and science is serious difficulties in organizing students' internships.

There is a way out of this situation. This is vividly demonstrated, above all, by those "points of growth" that have been identifies in recent years in the EAEU economies, science, and higher education. All leading experts unanimously indicate the need, based on the strategic goals of the states, to increase investment in the so-called "human capital." State funding of science and education should be a priority. 
At the same time, using successful foreign experience, the EAEU countries, Kazakhstan and Russia in particular, should launch the mechanism of participation of private companies together with universities in the training and retraining of personnel. The EAEU counties should stimulate the practice of creating training centers in enterprises, support by employers with subsidies that create conditions for work experience, training and retraining. In addition, the states should create tax incentives for those enterprises that co-finance staff training and retraining.

\section{Conclusion}

The EAEU counties experience a number of challenges in their economic development, which is caused by rapid growth of technological developments. It is highly necessary for these countries to actively develop their technological capacity. The central role in such strategies should belong to the higher technical education.

\section{References}

[1] Balashova, T. A., \& Lavryashina, T. V. (2014). Higher technical education: problems and tasks. Professional education in the modern world, 2(13), pp. 12-19.

[2] Gavrilova, N. M. (2015). Personnel infrastructure of the innovation system: problems and development prospects. Financial Analytics: Problems and Solutions, 9(243), pp. 23-34

[3] Gallyamova, L. I. (2017). Integration of academic science and higher education as a factor in the intellectual potential of Pacific Russia. Russia and the APR, 3(6), pp. 76-80.

[4] Government of Russia. (2012). The concept of long-term socio-economic development of the Russian Federation for the period up to 2020. Retrieved from http://www.consultant.ru/document/cons_doc.

[5] Kurakova, N. G., Zinov, V. G., \& Tsvetkova, L. A. (2017). The choice of scientific and technological priorities with the potential to create new industries: a system of measurable indicators. Economy of science, 3(3), pp. 67-78.

[6] Miller, A. E. (2017). Institutional restrictions on the development of innovative production technologies. Bulletin of the Faculty of Management SPbSEU, 1, pp. 87-96.

[7] Neshitoy, A. S. (2014). Assessment of the industrial potential of Russia and the level of its use (imperative to modernize industrial production). Strategy of Economic Development, 29(266), pp. 9956.

[8] (2017). Russia in numbers 2017: a brief statistical compilation. Moscow, Russia: Federal State Statistics Service.

[9] Sibirskaya, E. V. (2017). Transformation of the economy in the context of the formation of a national technology initiative. Bulletin of VolSU. Series 3, Economy. Ecology, 3(19), pp. 234-345.

[10] Government of Russia. (2018). Strategy of scientific and technological development of the Russian Federation. Retrieved from http://www.consultant.ru/law/hotdocs.

[11] Federal State Statistics Service of the Russian Federation (2018). Official data. Retrieved from http:www.gks.ru.

[12] Shcherbakov, A. P. (2017). Analysis of trends determined by the transformation of the technological structure. Transport business in Russia, 2, pp. 12-18.

[13] Polyanina, A. (2017). Digital economy: how do experts understand this term. Retrieved from https://ria.ru/science/20170616/1496663946.html. 